\title{
Mulheres trabalhadoras nos anos 1980, experiências feministas e transformações de si
}

\author{
Tânia Mara Cruz*
}

\section{Contextualização}

De acordo com estudos realizados, na década de 1990 observou-se um pequeno recuo na intensidade nos movimentos sociais de mulheres e/ou feministas e um relativo aumento da profissionalização do movimento com a participação de/em organizações não governamentais. A partir de meados de 2000, novos movimentos sociais por todo o país têm retomado o conceito de movimento social e organização popular (Pinto, 2010) e a vivenciar experiências semelhantes às que compõem os movimentos sociais da década de 1980, o que nos leva a trazer aqui a história de um movimento em particular, o Comitê de Mulheres de São Bernardo do Campo/SP, atuante entre os anos de 1983 a 1991.

Relacionar a história de movimentos sociais feministas com as $\mathrm{mu}-$ danças subjetivas nas mulheres que deles participam ainda encontra relativas resistências na história social, cujo objeto de estudo centra-se com mais frequência nas relações de classe e economia. No entanto, consideramos de vital importância refletir que as mudanças culturais e econômicas acontecem de modo dialético, fazendo com que mulheres pertencentes às classes trabalhadoras transformem muitos elementos de seu cotidiano e de suas relações

* Professora do Programa de Pós-Graduação em Educação - Mestrado em Educação da Universidade do Sul de Santa Catarina (Unisul). 
pessoais a partir de experiências sociais feministas. Em muitos sentidos, elas vivenciam o que alguns estudos afirmam existir em larga escala apenas para mulheres de setores médios, que o conseguem em função da equiparação econômica com seus parceiros e de novas concepções de gênero e poder. Este é o principal objetivo do trabalho aqui apresentado, que se baseará em parte nas fontes primárias do acervo da entidade, mas produzirá um diálogo com a memória pessoal e social através das narrativas das lideranças entrevistadas, sendo tratadas de modo imbricado as relações com a produção e a reprodução da vida que permeiam a sociedade capitalista.

O sentido de classe e de experiência ancora-se nas concepções de Thompson (1987, p. 10):

A classe acontece quando alguns homens, como resultado de experiências comuns (herdadas ou compartilhadas) sentem e articulam a identidade de seus interesses entre si, e contra outros homens cujos interesses diferem (e geralmente se opõem) dos seus. A experiência de classe é determinada, em grande medida, pelas relações de produção em que os homens nasceram ou entraram involuntariamente. A consciência de classe é a forma como essas experiências são tratadas em termos culturais: encarnadas em tradições, sistemas de valores, ideias e formas institucionais.

O autor articula as relações entre movimentos sociais e processos culturais com a constituição da classe como categoria histórica (e não decorrente, meramente, da inserção em determinadas relações de produção), pois afirma ser no processo de luta que trabalhadores(as) se descobrem como classe. Com o cuidado de evitar transposições mecânicas, refletimos sobre as tramas complexas de experiências de luta feminista que colocam em xeque a subordinação objetiva e subjetiva de classe e gênero em todos os níveis da vida humana. Em muitos momentos podemos acompanhar as trajetórias das mulheres entrevistadas nesse processo de constituição de identidade, ora em contraposição ao mundo masculino dentro de sua própria classe, quando o cotidiano doméstico estava em questão, ora como integrantes de movimentos sociais cujo antagonista era o Estado e, por fim, questionando patrões quando se inseriam em relações econômicas do trabalho nas fábricas, ressaltando a identidade de mulheres e trabalhadoras que as faziam agir. Ao mesmo tempo, em suas falas, ora críticas, ora fatalistas, notamos a presença do sentido de classe como cultura nas difíceis condições de vida e de sobrevivência dessas mulheres. 
Trazemos aqui elementos sobre a história de uma entidade de mulheres, o Comitê de Mulheres de São Bernardo do Campo (1983-1991), e damos a palavra a algumas das ativistas, numa busca reflexiva que é também nossa, pessoal e política. Assim o fizemos, pois participamos desse movimento, em uma trajetória comum no feminismo brasileiro, em que somos feministas e teóricas, simultaneamente. Mas nossa intenção historiográfica é ir além de um conjunto de histórias pessoais, pois, como afirma Smith (2010, p. 27):

A história oral prospera quando ultrapassa o modelo de simples coleção de histórias pessoais e se transforma em diálogo sobre o passado, estimulando novas interpretações históricas. O relato que eu conto só tem sentido quando estimula novas interpretações. Uma vez compartilhada, já deixa de ser a minha própria história. Cada entrevista pode ser um convite a uma cadeia de diálogos. Cria-se um elo que mantém vivos leitores e ouvintes na dinâmica da conversa, nas possibilidades de respostas, na busca de novas direções e possibilidades de interpretações das mais diversas sobre o que se viveu. A história oral pode democratizar o entendimento do passado porque nos permite imaginar a nossa experiência pessoal como algo que existe para ser compartilhado, como algo que poderia ser útil para uma comunidade de investigação mais ampla do que podemos imaginar.

Mas ser militante $e$ historiadora nos leva a querer, em nosso compromisso com a história, ampliar o debate para além de quaisquer fronteiras e buscar, como afirma Pollak (1992, p. 11), "a possibilidade, não de objetividade, mas de objetivação, que leva em conta a pluralidade das realidades e dos atos". A objetivação da memória, a partir de um cuidado historiográfico, pode combinar memórias de ativistas, documentos escritos e processos analíticos, já que objetividade e subjetividade se intercambiam dialeticamente nessa construção histórica da memória coletiva, nem por isso menos historiográfica.

O movimento social a ser analisado constituiu-se ao longo do tempo em uma situação de fronteira entre o movimento social de mulheres e o movimento feminista, em função de seu caráter popular, centrado na luta contra a carestia e por alimentação de menor custo, e de lutas por mudanças nas relações entre homens e mulheres. ${ }^{1}$ Cabe ressaltar que, pelas características

1 Arquivo Comitê de Mulheres de São Bernardo do Campo (ACMSBC) - Em defesa da organização popular, 17/05/1985. 
dos testemunhos obtidos no trabalho aqui apresentado, a categoria mulher se sobrepõe em muitos momentos à categoria gênero, mas esclarecemos que a perspectiva de fundo com que trabalhamos é de que gênero pode ser visto como significado de masculinidade e feminilidade em constructos culturais (atributos simbólicos disponíveis socialmente) e relações de gênero, como expressão de relações concretas entre homens e mulheres, homens e homens, mulheres e mulheres, mediadas pelos gêneros, em um fazer recíproco permeado por relações de poder e dicotomias (Scott, 1990, 1992). Quaisquer transformações em sujeitos ou em significados reconfiguram-se em novas relações de gênero, tanto no plano sociopolítico quanto no cultural, e perpassam, de modo transversal, as demais relações e os movimentos sociais (Paoli, 1991). Por fim, ao nos valermos de homens e mulheres, mantemos a utilização da categoria "sexo" como definidora do sujeito.

Alguns autores sugerem a conceituação de movimento social de mulheres para designar todos os grupos de atuação feminina que podem ou não incluir posições feministas, propondo uma subdivisão em função do conteúdo de suas reivindicações, como movimento por creches, por moradia, movimento feminista etc. Outra linha conceitual, na qual nos incluímos, estabelece uma diferenciação entre movimento feminista e movimento social de mulheres, mas em interação constante de práticas e significados. Os movimentos feministas, múltiplos em suas linhas, têm em comum a crítica à subordinação da mulher e a luta pelo fim da hierarquização entre os sexos em todos os planos da vida humana. Movimentos sociais de mulheres referem-se a todas as formas de movimentos com presença feminina, mas que apresentam reivindicações e objetivos relacionados às melhorias sociais de interesse coletivo, e não apenas nas relações de gênero. Nesse contexto, determinados movimentos sociais de mulheres desenvolvem práticas feministas sem se converterem em movimentos feministas propriamente ditos, na medida em que mantêm como tônica principal a luta por melhores condições de vida ou outras reivindicações afins (Singer, 1981; Souza-Lobo, 1991). Podem, ainda, efetuar uma fusão de interesses, iluminando as novas práticas, com ênfase na questão feminista, e convertendo-se em um movimento feminista no decorrer de sua trajetória.

O Comitê de Mulheres de São Bernardo do Campo, desde sua origem, tinha o objetivo de unificação de interesses como um marco político pela origem diversificada de suas militantes, mas que só se efetivou no decorrer 
de sua história. ${ }^{2} \mathrm{O}$ Comitê estruturou-se a partir do encontro entre mulheres operárias e dos setores médios, que juntas construíram uma trajetória de lutas por interesses feministas e por melhores condições de vida, sob o referencial de uma sociedade socialista conforme proposições de esquerda na década de 1980 (Alvarez, 1992; Delphy, 1994), particularmente presentes em setores da Igreja Católica e do Partido dos Trabalhadores. A nosso ver, o fato de esta entidade ter objetivos e desenvolver práticas feministas com regularidade ${ }^{3}$ e, ao mesmo tempo, estar em um Projeto Social por uma alimentação de menor custo, ${ }^{4}$ fazia com que ela transitasse em uma interseção política mais complexa entre os dois movimentos sociais, o feminista e o de mulheres.

O Comitê estruturava-se a partir de um trabalho de cogestão com a Secretaria de Agricultura do Estado de São Paulo na comercialização direta entre produtores e consumidores de leite. ${ }^{5}$ Havia um cadastro de consumidores de leite, composto majoritariamente por mulheres, embora houvesse homens que também participavam de reunióes específicas sobre o Projeto e eram convidados para as demais atividades. O Comitê possuía 300 sócias, que participavam de assembleias e reuniões nos bairros e efetuavam pequenas contribuições mensais. Em torno desse trabalho aglutinavam-se mulheres que realizavam atividades políticas diversas: campanha pelas Diretas Já; ${ }^{6}$ palestras sobre o socialismo ${ }^{7}$ pelos Direitos da Mulher; debates sobre a Reforma Agrária; apoio a movimentos políticos locais, como pela moradia; organização de cursos, debates e oficinas sobre a saúde da mulher, sexualidade, educação de filhos, saúde mental feminina; participação em encontros feministas nacionais e internacionais. As atividades ocorriam em diferentes espaços nos bairros (Associação de Moradores, Clubes de Mães, Igreja, Partidos) e, quando centralizadas, ocorriam em sede própria do Comitê. Este havia se instalado, sucessivamente, nos galpóes do Mercado Velho da cidade, na Câmara

2 ACMSBC - Estatuto do Comitê de Mulheres de SBC, 1984.

3 ACMSBC - Resoluções do I Encontro de Mulheres de SBC, s/d.

4 ACMSBC - Convocatória para a Passeata da Panela Vazia, out./1983; Avaliação do período experimental do projeto de leite a granel, julho, 1985.

5 ACMSBC - Movimentos Sociais e o Estado: Projeto de Leite, autonomia e organização - Documento de avaliação do projeto do leite, set. 1988.

6 ACMSBC - Ata da reunião preparatória das Diretas, s/d.

7 ACMSBC - Convocatória Cuba Hoje, palestra de Clara Sharf, 19/05/1985. 
Municipal, em salas alugadas e, por fim, na Casa da Mulher Nora Astorga, conquistada pelo Comitê em 1989, e custeada pela administração municipal.

$\mathrm{O}$ intuito foi compreender os significados atribuídos ao feminismo pelas militantes, complementando-o com as fontes históricas impressas disponíveis sobre a entidade. A partir de algumas perguntas gerais, indagamos como se lembravam da época de ativistas e o que nos teriam a dizer sobre suas vidas e o Comitê. No decorrer da entrevista outras perguntas surgiam, mas a proposta básica era de que houvesse um recorte da história de vida a partir das relações com a participação na entidade. Nosso objetivo, mais do que o diálogo com a história documental com o acervo da entidade, era analisar nas narrativas as possibilidades de transformação pessoal e coletiva de mulheres com origem operária ou rural que, em sua maioria, não possuíam escolaridade superior ou condições financeiras confortáveis. Deixamos de lado, propositadamente, análises sobre as relações entre concepções de feminismos e as políticas partidárias, religiosas ou sindicais na década de 1980, presentes no material mais amplo da pesquisa.

\section{Seleção e perfil das ativistas entrevistadas}

O Comitê tinha uma direção composta por uma diretoria e um conselho de representantes por bairro, além de contar com a participação de lideranças de bairro sem cargos, já que suas reuniōes eram abertas. ${ }^{8}$ No total, havia cerca de 35 mulheres na direção do Comitê, sendo a maior parte de donas de casas (ex-trabalhadoras rurais ou ex-operárias) e, em menor número, costureiras e professoras, assistentes sociais, funcionárias públicas, jornalistas e enfermeiras. Na diretoria concentravam-se as mulheres com escolarização média (três) ou superior (sete) e um pequeno número com outras escolaridades. Já no Conselho de Representantes (CR), havia uma predominância de mulheres com escolaridade básica incompleta, sendo que apenas algumas haviam terminado a escola básica, com 11 anos de estudo.

Selecionamos 12 lideranças da direção da entidade: Mara, Maria, Deta, Mariana, Isabel, Minervina, Juraci, Elza,Teresinha, Cida, Naná e Fátima. Nenhuma delas se declarava feminista antes de atuar no Comitê e a maioria

8 ACMSBC - Listas de presença das reuniões preparatórias do I Encontro de Mulheres de SBC 1983/1984 e ATAS 1984/1989. 
delas não possuía escolarização superior. Expressavam o perfil da base de apoio social do Comitê e, por isso, nosso interesse em conhecer e analisar como viam o feminismo e se houve ou não alteração em suas vidas a partir das experiências no Comitê.

Cada ativista foi entrevistada uma vez, por cerca de duas horas, no período de dezembro de 1993 a dezembro de 1995. Os maridos não concordaram em ser entrevistados. Apenas o marido de Maria, único que não pertencia aos meios operários e aceitava a militância, não teve sua entrevista aproveitada devido às respostas monossilábicas. Resultado, quem sabe, da presença da esposa, que não quis se ausentar durante a entrevista, ou porque ele considerasse a pesquisadora como mulher e feminista, o que talvez o tenha intimidado. A utilização de memórias femininas pode gerar situações em que só se consegue o protagonismo de mulheres, mesmo que homens tenham participado do processo de algum modo (Andrade, 2007). Em casos assim, o olhar de gênero pode ser tomado apenas pelas clivagens que as mulheres apontam sobre os homens, sendo a presença masculina composta por referências indiretas expressas nas suas narrativas. Por fim, buscamos textos e depoimentos pessoais em documentos e jornais da entidade, conforme o trajeto tecido pelo fio das memórias femininas, no intuito de organizar, de modo mais coerente para o leitor, as histórias narradas nas entrevistas e o nosso campo de análise.

Esclarecemos que todos os nomes citados nos jornais da entidade foram mantidos. As mulheres nomeadas pelas entrevistadas foram registradas apenas com as iniciais para preservar o anonimato das fontes. Em relação às entrevistadas, apenas os nomes de Maria e Mariana são fictícios por solicitação das mesmas. Apresentamos aqui o perfil das entrevistadas com as características à época da entrevista:

JURACI, 37 anos, separada, ex-marido operário e empregada doméstica. MINERVINA, 64 anos, viúva de lavrador e remunerada pela Pastoral Católica. Ambas negras, filhas de trabalhadores rurais, com até quatro anos de escolaridade, trabalharam desde jovens no campo e depois como empregadas domésticas e arrumadeiras em hospital, ou hotel, ou como ativistas remuneradas;

FÁTIMA, de origem rural, 42 anos, separada, ex-marido operário e ela também operária. CIDA, de origem rural, 52 anos, separada, ex-marido pedreiro, depois motorista, e ela, ex-comerciária e costureira autônoma. DETA, de origem urbana, 47 anos, casada, marido operário, com 
formação de magistério, mas não trabalhava mais como professora e era vendedora autônoma. Todas brancas, com escolaridade de 11 anos; TERESINHA, ex-operária e dona de casa após o casamento. MARIANA, viúva, ex-empregada doméstica e ex-operária, no momento vivendo de pensão de viúva. Ambas eram brancas, de origem urbana, casadas com operários, tinham 58 anos e possuíam até quatro anos de escolarização;

ISABEL trabalhou como lavradora, empregada doméstica, vendedora e, depois, firmou-se como costureira autônoma. ELZA, lavadeira e, mais tarde, costureira autônoma. NANÁ, antiga dona de casa e que aprendeu a trabalhar com produção de roupas de lã em uma oficina no Comitê, criou uma confecção própria e, junto com seu marido, ali trabalhavam. Mulheres na faixa de 43 a 47 anos, todas brancas, de origem rural, com até quatro anos de escolarização e casadas com (ex-)operários. MARIA, 48 anos, enfermeira técnica em indústrias e hospitais, casada com executivo e ex-padre. MARA, 36 anos, professora com escolaridade superior (educação física) e casada pela quarta vez, no momento da entrevista com marido bancário e que então administrava o posto de gasolina do pai, aposentado. Ambas brancas, de origem urbana e filhas de operários, mas com padrão aquisitivo superior às demais entrevistadas.

Os pais de todas elas eram operários ou lavradores pobres, sendo que dois deles obtiveram ganhos financeiros no decorrer da vida, como os pais de Mara e de Maria. Todas elas migraram de diferentes estados do Brasil para São Bernardo, nas décadas de 1960 e 1970, com exceção de Mara, que era da cidade de Sáo Paulo, capital. Sobre a militância anterior ao ingresso no Comitê de Mulheres de SBC, apenas Maria e Mariana eram militantes de esquerda desde a juventude e Minervina, Juracy e Isabel eram ativistas de Clubes de Mães e Pastorais da Igreja Católica progressista. As demais haviam iniciado seu ativismo político no Comitê de Mulheres de SBC.

\section{A construção de uma rede alternativa de sociabilidade}

O trabalho âncora do Comitê foi, durante a maior parte de sua existência, o Projeto do Leite, em convênio com a Secretaria de Estado de São Paulo e em parceria com outras entidades de mulheres da Grande São Paulo. 
Possuía uma coordenação conjunta, que interligava os dois postos centrais e oito bairros redistribuidores. A rede de trabalho envolvia funcionárias dos postos e voluntárias dos bairros, além da atenção indireta da direção da entidade. No cotidiano, os problemas eram muitos: a perecibilidade do produto, as dificuldades financeiras, além das disputas entre ativistas que almejavam uma quantidade maior de leite para o bairro em que eram líderes. Se estes fatores dificultavam as lutas relativas ao feminismo, foram também responsáveis pela criação de sólidos vínculos entre as mulheres. O clima mobilizador dos primeiros anos da entidade, em meados da década de 1980, foi lembrado com saudade:

Uns momentos bons que eu tive foi quando a gente foi a São Paulo pra gente lutar, foi na Secretaria da Agricultura, a conquista do leite e que eles queriam tirar. A gente ia enfrentar aquele secretário que só enrolava a gente, aquilo lá foi importante na minha vida. Foi uma vitória, pelo menos a gente mostrou que tinha força, a gente reunia aí mil mulheres, era só a gente fazer um movimento, soltar um pouquinho de panfleto, que a gente reunia as mulher, as companheira e ia embora. Acho que valeu mesmo, pena que hoje não tem mais. (Entrevista de Elza).

As motivações expressas pelas lideranças do Comitê relacionavam-se à valorização social de, juntas, desafiarem e conquistarem o direito à participação política e experimentarem um sentimento de força coletiva, resultado das constantes disputas políticas que davam a tônica do movimento. As mulheres que trabalhavam no Projeto, em sua maioria, eram voluntárias (com exceção dos dois postos centrais com quatro mulheres remuneradas), casadas, com filhos e estavam afastadas há algum tempo do trabalho externo à casa. Tinham no trabalho nos postos de leite um papel de referência política e pessoal, pois eram pontos de encontro feminino nos bairros, onde discutiam seus problemas pessoais e as notícias do momento. Em cada bairro, as atividades ocorriam em diferentes espaços: nas casas das associadas, nas sociedades de amigos de bairros, nos núcleos do PT e na sede da entidade no centro da cidade.

Sobre o significado do trabalho, temos o depoimento de Lina, que participava voluntariamente de um revezamento em um dos postos centrais, o de Ferrazópolis, no jornal da entidade: "no começo a gente não entendia muita coisa, mas aos poucos foi tomando consciência. Eu teria que vir trabalhar só 
15 dias, mas eu venho todos os dias". ' O envolvimento com o Projeto repercutia no mundo familiar e gerava rupturas. O marido aposentado de Isabel, apesar de ter sido metalúrgico atuante, quis separar-se por causa da participação dela (Entrevista de Isabel). O tempo da dona de casa, que normalmente se organiza em função das atividades domésticas, do trabalho do marido e do horário escolar das crianças, altera-se com o envolvimento político, havendo uma inversão em que o tempo e o ritmo do trabalho passam a ser calculados em função das atividades de fora, ressignificando o político como uma necessidade pessoal.

Mas os maridos, como o de Isabel, viam com hostilidade ou certa reserva a participação política das esposas:

O Comitê na minha vida e do D. [marido] foi um inferno. Ele achava que eu indo para o Comitê era perdido, era libertinagem, era se perder, era ser cantada por outros homens, certo? No Comitê eu encontrei isso, aprender o nosso lugar, o nosso desejo. E tanto que eu não fui para os movimentos de participar das greves porque ele me levasse, fui por conta minha, ele botava grade, botava cadeado! (Entrevista de Isabel).

$\mathrm{O}$ apego das mulheres a esse trabalho era tão forte que a resistência ao seu término foi imensa, mesmo quando a qualidade baixou de $\mathrm{A}$ para $\mathrm{C} \mathrm{e}$ o custo do leite já era semelhante ao das padarias. Entre múltiplas tensões, as mulheres ancoravam-se na sociabilidade construída, a ponto de servir de motivação para Deta recriar sozinha, anos depois, outra rede de comércio do leite, mantendo contato com antigas ativistas. Saudosa, falou daquele tempo:

O que eu gostava mesmo era de participar daquelas reuniôes, de sair para o movimento e passeata, aquelas reuniôes que a gente fazia ali na Câmara, no dia a dia 'tava discutindo todos os problemas, geral, e 'tava discutindo o problema de alguém e conversando com o pessoal. Ah, era legal demais! Foi um espaço que acabou e faltou. (Entrevista de Deta).

9 ACMSBC - SEMPREVIVA, nº 4, maio-jun. 1986. 


\section{Interseções e aprendizagens nos encontros feministas}

Os encontros feministas, com a participação de 500 a 700 mulheres, de grupos e lugares os mais diferentes, deixaram uma marca profunda na memória de algumas ativistas, e mostraram de que maneira se deu o jogo de influências recíprocas entre movimento de mulheres e movimento feminista. No espaço de dois anos sucessivos, o Comitê participou de três encontros. Em 1986, do III Encontro Latino-Americano e do Caribe e do VIII Encontro Nacional Feminista, ambos na cidade de Bertioga, estado de São Paulo. Em 1987, do IX Encontro Nacional Feminista, na cidade de Garanhuns, estado de Pernambuco. ${ }^{10}$ Eles proporcionaram momentos de entusiasmo e experiências ricas de uma nova forma de sociabilidade: para ir a esses encontros, as mulheres necessitavam arrecadar dinheiro, organizar um esquema (palavras delas) para os filhos, negociar com os maridos e, para muitas, era a primeira chance de sair de casa sem o marido e os filhos. Mesmo quem não os frequentava, lembrava-se deles: "tinha os encontros, mas eu não cheguei a participar, mas as colega que ia passava pra gente, como a gente tinha que ser, acho que clareou muito" (Entrevista de Fátima).

A expressão utilizada "como a gente tinha que ser" revela a diversidade de modelos, conhecidos e vivenciados nos encontros, que exerciam sua influência sobre a constituição da identidade das militantes.

O IX Encontro Nacional Feminista de Garanhuns foi o mais marcante para as militantes, tanto por seu caráter popular, que proporcionava uma espécie de identificação coletiva de classe, como pelas novidades descobertas dos diferentes feminismos em um só. Abaixo, alguns excertos do jornal da entidade, ${ }^{11}$ produzido após a volta do encontro, nos trazem suas reflexões:

Eu adorei, estão com tanta vontade de ir pra frente que dá vontade de ir junto com elas [...] me impressionou a história de uma mulher que tinha oito filhos e que disse que estava tão mal de vida que gostaria que eles morressem. Por não ter comida, plantou um pé de mandioca no meio do canavial e o capataz veio ameaçá-la por isso, mas ela disse que está incentivando outras mulheres para fazerem o mesmo [...] A gente sente na pele o que elas sentiam. (Lina).

10 ACMSBC - Avaliação do IX Encontro Nacional Feminista, set. 1987.

11 ACMSBC - SEMPREVIVA, nº 7, set.-out. 1987. 
Tem uma oficina que eu não gostei, a das lésbicas, estava doida pra ir, eu estava curiosa para saber como elas fazem, porque elas gostam de mulher, mas elas vieram com um questionário, com umas perguntas difíceis de responder, mas eu nunca tinha visto uma lésbica na minha frente e aprendi muita coisa. (Maria S.).

Eu gostei, queria saber o que era o feminismo, se a gente quer conquistar gente no nosso meio tem que ser maleável, eu me senti Igreja [...] Ser feminista é lutar para que a mulher veja respeitado o seu direito, não escravizar outra mulher [...] voltar pra casa e enfrentar os problemas de casa é um problema sério, mas também a gente teve o espaço só pra gente. (Jupira).

Nos descobrimos feministas, só que não nos chamávamos por este nome. (Ana).

A diversidade de grupos presente nos encontros colocava lado a lado o universo da teorização das feministas dos setores médios e a curiosidade prática dos movimentos sociais de mulheres em transição para o feminismo, proporcionando interações reflexivas para as ativistas. No entanto, a volta para casa nem sempre era tranquila e havia o choque de expectativas, como vemos na fala de Geralda: "gostei, participei da oficina Muda e Linguaruda, aí aprendi a conversar [...] eu tinha medo [...] sinto que me libertei [...] só que meu marido falou que o próximo não é pra eu ir". ${ }^{12}$

Pode-se observar que a descoberta de novas identidades e a contraposição de uma forma de viver não as impediam de pensar no cotidiano difícil que as aguardava, mesmo sem conseguirem, às vezes, questionar as relações de poder vividas nesse cotidiano quando para ele voltavam. A liberdade do encontro havia ficado para trás com seu clima de festa e possibilidades, como afirma Bakhtin (1987, p. 77):

A festa marcava, de alguma forma, uma interrupção provisória de todo o sistema oficial, com sua interdição e barreiras hierárquicas. Por um breve espaço de tempo a vida saía de seus trilhos habituais, legalizados e consagrados, e penetrava no domínio da liberdade utópica. 


\section{O conhecimento do corpo}

O direito ao corpo foi uma bandeira que imprimiu uma marca diferenciadora entre o movimento feminista e os demais movimentos sociais. Se o corpo em nossa sociedade é um dos espaços mais importantes por onde passa o exercício do poder e da liberdade, para as mulheres ele é o lócus principal sobre o qual se estrutura a sua dominação. O corpo cansado da dupla jornada, afogado em inseguranças ou normas científicas para a obtenção do prazer, o corpo-doador da maternidade e todas as suas implicações, o corpo ginecológico, menstruado, abortado em condições precárias, esterilizado, violentado até nas formas mais sutis, como o corpo-estético, construído pela indústria da beleza. E sobre o corpo, o discurso religioso do pecado, corpo-penitente, ou o discurso científico, corpo-disciplinado. Romper com a fragmentação de uma cultura que fez do espírito o único sujeito, como afirma Chauí (1982), é tarefa que vai além do feminismo, mas tem nele o seu maior aliado. O Comitê de Mulheres contribuiu para que as mulheres passassem a se ver como donas de seu corpo, conhecendo-o e vivenciando-o de forma mais livre em oficinas e grupos de reflexão.

Nas oficinas de autoconhecimento, ministradas pelo Coletivo Feminista de Sexualidade e Saúde (SP) ${ }_{13}^{13}$ muitas mulheres se viam pela primeira vez:

Eu nunca vou esquecer a experiência de uma médica, a M., ela fazia uma roda de mulheres e a gente se examinava. Nesse movimento a gente passou a conhecer mais da mulher, ver como é que funcionava, ver como formava a feridinha, lembra? Era uma coisa de sonho, viu? (Entrevista de Cida).

Lentamente se apropriavam daquele saber necessário, em um processo de verem-se diferentes perante uma mesma situação:

$\mathrm{Na}$ parte sexual eu vi que tinha mulher ali, não é tanto o meu caso, mas tinha colega que tinha que ser submissa ao homem nesta parte; mesmo ela estando magoada, fechada, tinha que satisfazer ao homem em qualquer circunstância. (Entrevista de Fátima).

13 ACMSBC - Relatório de avaliação do curso de saúde, jul. 1987. 
Mas, ao mesmo tempo, num sutil e difícil jogo de se verem no espelho da opressão, pois no desenrolar da entrevista, o "elas" virava "eu" e, ao final, "nós", no qual Fátima se incluía, em um processo de construção de uma nova identidade comum:

[...] o meu marido tinha o problema da bebida, mas chegava na hora do sexo ele queria e não entendia, e eu até tinha sexo com ele, fingia que 'tava tudo bem, que eu achava que tinha que agir daquele jeito porque ele era meu marido, então, ali clareou muito: pra que eu vou fingir, eu vou enganar a mim mesma, só pra deixar ele contente e ele nem ter a compreensão nesta parte? Amanhã ele já 'tá me pisando [...] Muitos papos ali no Comitê, às vezes eu não tinha coragem de colocar isso lá, diante das colegas que era mais experiente em falar nisso, mas pelo menos dentro de mim eu consegui me libertar disso e até mesmo eu poder orientar uma colega que 'tava passando por isso. (Entrevista de Fátima).

O jogo entre individual e coletivo nos processos de consciência, de subjetividade e intersubjetividade, como diria Martins (1989), pode ser observado aqui. Inicialmente, a subjetividade alienada, expressa na frase "não é tanto o meu caso", expande-se na intersubjetividade e no perceber-se no outro para, ao final, se propor novas relações como "orientar uma colega", em um sentimento de solidariedade e identificação.

Também para Juraci, o Comitê abriu a possibilidade de equacionar as contradições entre a sua atuação religiosa nos Clubes de Mães e suas dúvidas em relação ao aborto provocado. A partir das experiências pessoais de gravidez indesejada e do desejo de aborto, identificava-se de perto com as demais mulheres da favela que, não raro, morriam devido ao aborto malfeito através do uso da "bassora gatumba" (palavras dela, nome de origem africana dado à piaçava cortante), que as mulheres agrupavam em espetos e introduziam no útero provocando sangramento:

No Comitê, eu discutia "mas como, vai sair todo mundo matando?", e a MA. [outra diretora da entidade] dizia: "o aborto legalizado é só pra que as mãe não morra tanto como vejo morrendo aí. [...] vai parar de ter aborto clandestino pelas mulheres provocarem o aborto pelas curiosas".

Então vai ter médico e, tendo condições, a pessoa faz. (Entrevista de Juraci). 
O resgate de si enquanto um sujeito autônomo, não mais objeto sexual do outro, mas com leitura de seu próprio desejo e direito à iniciativa, pode ser analisado nas recordações de Maria sobre o antes e o depois de reflexões coletivas: "de repente tua vontade era morta, era apagada porque você só esperava o momento do teu companheiro te procurar, essa é uma coisa bonita que eu aprendi no Comitê, porque a partir daquele momento chegou a minha vez, aí pronto!" (Entrevista de Maria).

Outras questões se seguiram, em um processo de reflexão iniciado, mas não finalizado: "ainda não tenho a iniciativa sexual pela vergonha, pelo jeito que eu fui criada [...], talvez no futuro eu possa me libertar disso também" (Entrevista de Elza). A cada atividade, tudo se desarrumava:

Teve uma época que virou a minha cabeça, foi o curso de formação, ${ }^{14}$ onde foi mostrado que não existe na sociedade um órgão mais repressivo, sexualmente, que a família [...] Você tomou conhecimento disso e aí pra frente, como é que vai ser? Eu ficava me perguntando três, quatro anos depois: e agora, meu deus, não existirá um meio-termo? (Entrevista de Maria).

Bosi (1992, p. 114) descreve que esta relação com o conhecimento e uma possível insubmissão têm um preço psicológico a pagar, porque:

A mudança de atitude exige uma reorientação intelectual, um rompimento com vínculos sociais e uma reestrutura da experiência passada. A mudança de atitude causa uma desordem nas relaçôes sociais. Toda criatura reage defendo-se da desorientação. Defende, pelos meios mais econômicos ao seu alcance, a orientação global necessária à sua atividade, ainda que isso pareça irracional.

Dúvidas e necessidades revelam a construção permanente de si e da busca pelo novo conceito de liberdade, sinônimo de perceber-se como um sujeito capaz de transformar-se, ou seja, um sujeito que se sabe cultura. Nas mudanças ocorridas entre as mulheres, o feminismo surge como parâmetro explicativo para dificuldades antes percebidas como apenas suas, de imaginar-se desviante do que imaginava ser um comportamento padrão para to-

14 ACMSBC - Avaliação do curso de formação política, nov. 1985. 
das as outras mulheres. De acordo com suas histórias de vida, cada mulher ressignificava as práticas feministas vivenciadas.

\section{Trabalhar: a que (quem) será que se destina?}

Os questionamentos em relação ao mundo do trabalho, a partir da crítica feminista, puderam ser agrupados em três instâncias que aparecem mescladas nas falas femininas: a) percepção das diferenças entre homens e mulheres na divisão sexual do trabalho; b) construção de novas expectativas, para si ou para o conjunto das mulheres; ec) revisão do conceito de trabalho doméstico.

Tendo com base experiências, como a cooperativa de lanofix e os grupos de reflexão, surgiu o trabalho como espaço de autonomia, criação e saída do trabalho doméstico repetitivo:

A M., a psicóloga, [que prestava atendimento na Casa da Mulher e não outra ativista MA., diretora da entidade] disse que a gente tinha que se sustentar e fazer o que gosta. Aí percebi que tinha que trabalhar para mim, para meu sustento. E com a lanofix foi a primeira vez que um trabalho era meu e tinha a ver com o que eu quis [...] Antes eu lutava, mas era em segundo plano. (Entrevista de Naná).

Ele [marido] diz que eu não preciso disto, que ele é aposentado, ele trabalha. Eu sei que não preciso trabalhar, que o que ele ganha dá muito bem para a gente sobreviver. [...] Eu adoro aquela confecçãa, aquelas roupas que eu costuro, aquilo é a minha vida, é o meu lazer! [...] meu marido já falou: "Para de trabalhar fora e eu te pago um salário mínimo para cuidar da casa! Eu, hein!!!” (Entrevista de Elza).

Para Naná, a fala da psicóloga em um contexto coletivo lhe proporcionou um insight, mudança que a entusiasmou tanto que convenceu o marido a aprender lanofix e a abrirem juntos a confecção que existia até o momento da entrevista. Elza voltara à fábrica como assalariada e sua fala demonstrava as ambiguidades das relações entre trabalho doméstico e as relações amorosas, não aceitando as propostas de seu marido, que queria ser também seu patrão.

Essa ambiguidade presente em muitas mulheres das classes trabalhadoras, de preferir o trabalho doméstico à exploração do capital, e buscada como 
forma de se libertar da dupla jornada de trabalho, passava a ser problematizada. Se a situação da dupla jornada é quase inevitável, já que é difícil assalariar outra mulher em seu lugar, as ativistas feministas questionavam essa alternativa de ficar em casa e reforçavam a necessidade de separar amor de sobrevivência/exploração.

$\mathrm{Eu}$, como feminista, vou conseguir fazer isso [trabalhar e construir sozinha a casa no Mutirão] pra poder ter certeza se nós 'guenta ou não. Eu vejo muita gente "você gosta de fulano?", "não, vou casar porque preciso de ajuda" [...] Eu não, preciso de amor [...] Eu sempre trabalhei, tudo, mas não me via valor nenhum. Achava que meu marido era meu marido e que eu tinha que obedecer ele. Eu tinha esse modo de pensar e depois do Comitê eu já via ele de outra forma [...]. (Entrevista de Juraci).

Duas antigas militantes, ao voltarem ao mundo das fábricas, também reviram e politizaram de modos distintos a construção de um sujeito feminino coletivo:

Eu casei e fiquei dez anos dentro de casa, pia, fogão, tanque, cuidando dos filho, do marido, pra mim era bom, vivi aquele momento [...] Se fosse dias de hoje [...] Tenho mais claro na minha mente pra cobrar as coisas que eu acho que eles não dá, o direito da gente, que nem trabalhar fora. Agora vai reempregar de novo [na Multibrás, antiga Brastemp] e eu vou dar nomes de colegas, porque eu acho muito importante ter mais mulher. Agora a gente tem mais liberdade de direito, os colegas discriminam, acham que a gente não pode igual a eles, a gente não deixa barato mais. Foi o tempo que a gente ficava calada. (Entrevista de Fátima).

Uma trabalhadora fala "esse braço meu está inchado, porque quando eu saí do meu serviço fiquei duas horas lavando a fralda dos filho que era pra secar, pra levar no outro dia na creche". A sobrecarga de serviço dela, a própria firma poderia estar oferecendo. (Entrevista de Maria).

As agruras e os deleites do trabalhar fora de casa numa sociedade capitalista, contradição básica do capital ao permitir e explorar o trabalho feminino, estão presentes nas falas das entrevistadas. $\mathrm{Na}$ autoafirmação feminina de Fátima, ao argumentar o direito ao trabalho, no sentido de ter mais mulheres, 
ou na expressão de sujeito coletivo "a gente”, de Maria, que trabalhava como enfermeira em uma empresa química onde $40 \%$ eram mulheres, e atribuía as doenças das mulheres na fábrica à dupla jornada.

$\mathrm{Na}$ época da militância, o marido de Mariana, antigo militante do PC, sindicalista e recém-aposentado, reclamava de sua participação intensa e, para sair de casa, ela necessitava fazer primeiro todo o serviço doméstico, às vezes até tarde da noite. Teresinha, apesar de considerar a tarefa doméstica como atribuição feminina e sua, vivia situação semelhante:

Ele achava ruim, eu nunca liguei. Mandava brasa no serviço todo e ia [...] Se ele falasse, a gente também ia falar! Porque eles podem ir no lugar que quer, eles podem [...] Agora, a gente faz o serviço da gente, a gente vai, é o tempo da gente. A gente tem esse direito. (Entrevista de Teresinha).

Apesar de Teresinha criticar a desigualdade de poder, não o fazia em relação à divisão do trabalho, pois o via segundo a lógica da complementaridade: homens e mulheres têm deveres diferentes, mas se cada um fizer a sua parte, terá direito de dispor de seu tempo livre e do direito de ir e vir, decorrente da igualdade geral entre homens e mulheres. Nota-se, aqui, como alguns princípios do feminismo liberal serviam de base para a justificativa da participação feminina. Para algumas, as fortes tensões conjugais só acabavam quando os casamentos terminavam, por iniciativa própria ou viuvez. Após o término do Comitê, Mariana ficou viúva e afirma, só então, ter praticado uma divisão de trabalho com o restante da família e, depois, em um fugaz novo casamento, mas que se rompeu à época da entrevista por ter imposto essas regras antecipadamente.

Das entrevistadas, ainda que duas delas (Teresinha e Isabel) manifestassem um olhar essencialista e naturalizante atribuído ao trabalho doméstico, apenas Teresinha o assumia como seu, já que Isabel reclamava e exigia que o marido e os filhos dividissem com ela a sobrecarga. Numa visão intermediária e original, a observação de Deta sobre a empregada doméstica reflete a migração do senso comum essencialista para a natureza humana em geral e não mais da mulher, quando indagada sobre a possibilidade de alguém (que ela interpretou como a esposa) gostar do trabalho doméstico: "Acho que não. Agora ela [a empregada] só cantando. É que tem gente que tem o dom, não é? Eu acho que não existe dom pior!" (Entrevista de Deta). 
Como podemos ver nos depoimentos que se seguem, a concepção a respeito do trabalho doméstico é, em geral, negativa:

Com o primeiro marido foi aquele negócio de casadinho de novo, tenho que fazer a comida. Eu dava aula de natação no Jabaquara, vinha assim voando, aquilo era minha obrigação. O Comitê e todo o resto me ensinou que não precisava ser assim, nunca mais. (Entrevista de Mara).

Não peço [para o marido fazer o trabalho doméstico] porque ele fala que é obrigação de mulher, e eu fico quieta para não arranjar encrenca. Eu falo “serviço doméstico é amaldiçoado!". Agora vou pintar a casa e aí, depois, arranjar uma faxineira uma vez por semana. (Entrevista de Elza).

Já passamos uma fase [sem empregada] dividindo tarefa, mas começou um mal-estar tão grande... Ninguém suportava mais ninguém, estava todo mundo à flor da pele, porque não estava acostumado a fazer aquele serviço, porque sempre teve mulher no comando das coisas. (Entrevista de Maria).

O sentimento de solidão e inutilidade observado no trabalho doméstico fazia com que as mulheres trabalhadoras buscassem uma saída na militância política o que, por sua vez, acirrava ainda mais a visão negativa sobre o trabalho doméstico. Isto levava à possível contratação de outras mulheres para o serviço doméstico a fim de diminuir as tensões dentro de casa, como nos casos de Deta, Elza, Mara e Maria.

\section{As difíceis mudanças nas relações de gênero}

As mudanças na vida das ativistas durante a participação no Comitê continuaram mesmo após o término da entidade. Revelaram as difíceis relações entre as mudanças subjetivas e objetivas, sendo que algumas conquistas se mantiveram, mas outras foram perdidas, pois necessitavam de mudanças sociais ou de um grupo que as constituísse e as consolidasse em uma identidade coletiva de suporte. Situaçóes cotidianas do poder masculino, como tomadas de decisão, restrição de circulação ou resistências a uma nova divisão sexual do trabalho, foram fatores que levaram uma parcela significativa dessas mulheres a se separar. Das nove casadas, três se separaram durante a 
participação no Comitê. Algumas foram levadas a temer novos casamentos e a escolher com mais cuidado seus novos parceiros a partir da compreensão do feminismo:

Se o homem está fazendo serviço dentro de casa de pedreiro, a mulher também tem que ajudar [...] por que não um homem lavar louça? Se eu casasse agora, eu ia deixar bem claro, não ia casar no escuro que nem eu casei e, se no claro não dá mais [se o homem não aceitar...], então eu vou ficar na minha, eu não casava não, estou tão bem [...]. (Entrevista de Fátima).

Não caso hoje de branco, já penso em casar de lilás, porque lilás é feminista, feminino, a cor do feminismo. Posso até casar simbolicamente, mas já apareceu pedido de casamento e na hora de casar memo (sic) eu digo: "A vida de casada é boa, mas a de solteira é melhor." (Entrevista de Juraci).

Outro dia mesmo fui no baile e ele [namorado] me encontrou, estava sozinha, mas ele já achou ruim, e eu, "vim no baile pra dançar!" Aí ele já questionou, pra mim é uma pessoa que não dá [...]. (Entrevista de Cida).

Nas situações externas, o quadro se complicava e as estratégias adotadas só eram possíveis devido à autoestima conseguida anteriormente, já que a dominação masculina estava presente no emaranhado das relações sociais, na divisão social e sexual do trabalho. Quando entrevistada sobre a confecção de sua propriedade e de seu marido, Naná revelou a perversa realidade em que vivia. Ao saírem para a compra de matéria-prima, sentia na pele o tratamento diferenciado:

As vendedoras o chamam pelo nome, explicam tudo para ele e me ignoram. Penso que talvez elas nem saibam meu nome, não se dirigem a mim. Faço de conta que não percebo, entro na conversa, dou opinião, discordo dela em alguma coisa e vou andando atrás [...] Eu nem ligo, vou entrando na conversa. (Entrevista de Naná).

$\mathrm{Na}$ afirmação da resistência individual à invisibilidade, ressaltando inclusive um suposto não sofrimento, Naná deixava de relacionar a discriminação com a necessidade de uma ação coletiva pela transformação na sociedade em que estava inserida. 
Nesse recuo possível na consciência política destas militantes (Iasi, 2002), houve uma parcela de ativistas que, após o término da entidade, retornou à sua vida de origem. Saudosas e tristes, viviam em desacordo com suas necessidades e com dificuldade de construir uma nova relação afetiva e sexual com o marido, apesar do desejo de mudança. Algumas transformações duraram apenas quando da existência do grupo de mulheres, que estimulava um questionamento constante e oferecia apoio.

Fico mais em casa, não tenho tempo para sair [choro] [...] Ele [marido] desde que se aposentou não gosta de sair pra passear, só dorme. [...] (Entrevista de Teresinha).

Estou vivendo à base de calmantes, meu marido está aposentado e passa o dia a dormir. Meu corpo fica até tremendo. (Entrevista de Lina).

Algumas histórias nos foram contadas em meio a lágrimas e desesperança e refletiram o isolamento e a falta de projeto de vida após o término do Comitê, sentimento de solidão maior para as entrevistadas que permaneciam casadas e com idade acima de 45 anos. O contato com as práticas feministas, por ser tensionador, nem sempre desembocava na possibilidade de criar as próprias regras e de assumir o controle de suas vidas. Das 12 entrevistadas, duas nos demonstraram tristeza, como Teresinha e Lina, e a terceira, Naná, nos apresentou as dificuldades no mundo do trabalho fora de casa. Houve ainda histórias similares de mulheres próximas a elas, que giravam na órbita do Comitê, revelando situações de opressão não resolvidas, como vemos nesses relatos:

Estes dias eu encontrei a S. do Silvina, e ela disse: "ah! Eu tô parada dentro de casa sem fazer nada, tô lavando, passando, cozinhando!". Eu falei pra ela: "você tá achando boa esta vida?". Ela disse: "mais tranquila" [...] Eu falei, "vai pra rua, fazer alguma coisa", e ela "ah [...] depois que a MA. [diretora do Comitê no bairro que ela morava] foi embora acabou o Comitê! [...]. (Entrevista de Deta).

Veja a L. Era lutadora, tinha iniciativa e olhe que apanhou muito daquele marido. Viviam brigando porque ela não aceitava o jeito dele: mulherengo, jogo de futebol no domingo, ele não queria que ela trabalhasse. Hoje ela 'tá 
lá no sul, grávida do quarto filho, que o marido disse que lá no sul mulher tem que dar um filho homem. E fez ultrassom e é menina. Não apanha mais porque aceita tudo que ele faz ou manda ela fazer. Vida de mulher é um sofrimento, não é? (Entrevista de Naná).

São memórias sobre mulheres que acompanhavam o movimento e tinham nas lideranças suas referências políticas, mas que, na ausência delas e do movimento, retrocederam aos seus patamares iniciais de isolamento doméstico. A aparente tranquilidade na fala de $S$. faz Deta perceber o sentimento de inutilidade da colega em relação a si mesma (o sentimento de inutilidade sobre o próprio trabalho doméstico visto como "sem fazer nada") e, ao tentar animá-la, recebe de volta o sentimento nostálgico sobre o passado coletivo das práticas do Comitê.

A fala de Naná sobre L. é um tanto complexa e, no entanto, coerente com o que pensava sobre si mesma, ao dizer ter modificado seu marido, mas sentir-se discriminada pelas vendedoras, como falamos anteriormente. Atribui a desistência de Leonilda quase a uma naturalização da desigualdade, já que "vida de mulher é um sofrimento", parecendo estar embutida em sua fala a dificuldade ou a impossibilidade de grandes mudanças sociais. De volta ao seu mundo cotidiano de não militância, Naná parece operar uma cisão entre mudanças pessoais e mudanças sociais mais amplas, o que a impede, provavelmente, de perceber o sentido de continuidade da luta coletiva de mulheres.

\section{O futuro}

O grupo, que funcionava como um espelho, devolvendo às mulheres a imagem de suas necessidades, havia se quebrado. A existência do Comitê, que encerrou suas atividades de modo não oficial a partir de 1991, era, para algumas, uma condição básica não só para debater modelos alternativos de ser mulher, como um espaço para a intersubjetividade, na qual as mulheres se reconheciam em outras e intercambiavam problemas e soluções. De modo bastante enfático, as mulheres revelaram o papel do grupo na construção de suas identidades individuais, mas que funcionavam numa relação dialética com a identidade de grupo organizado de mulheres.

Apesar da realidade de uma sociedade de classes e da forte hegemonia masculina, mudanças foram possíveis no cotidiano dessas mulheres 
trabalhadoras e de setores médios. O cotidiano, considerado aqui como um espaço vital das ações humanas, era o lócus da politização do privado que interagia com as manifestações coletivas, gerando novas necessidades e formas peculiares de satisfazê-las. As ativistas do Comitê faziam reivindicações ao marido, à família, ao Estado e à sociedade como um todo. Eram solidárias com as militantes sindicalistas nas fábricas, nas comemorações de 8 de março (Dia Internacional das Mulheres), na referência em seus jornais sobre a luta das trabalhadoras em muitos lugares do Brasil e do mundo, participavam da campanha pela reforma agrária ou pelas eleições diretas. Ao refletirem sobre seu corpo ou ao adquirirem status político na atuação no bairro e na cidade, passaram a valorizar a si mesmas, o que, por sua vez, as levava a enfrentar novas experiências e desafios.

Todavia, constatamos que houve uma divisão na percepção da relação entre ações coletivas e mudanças individuais. O sentimento de saudade do movimento para nove das entrevistadas estava ligado às necessidades pessoais e não à compreensão de que um trabalho coletivo pudesse ser transformador da situação social para o conjunto das mulheres, principalmente as trabalhadoras. De modo contraditório, mesmo avaliando que o movimento social desenvolvido pelo Comitê era o responsável pelas suas mudanças subjetivas, poucas delas apontaram a necessidade de novos movimentos sociais para mudanças futuras. É como se o trabalho da entidade tivesse sido mais importante para suas mudanças pessoais do que para mudanças das relações de gênero na sociedade como um todo.

A compreensão do sujeito histórico e coletivo envolve processos de consciência que estão relacionados com as práticas da entidade, mas também com o momento histórico vivido por elas na década de 1980 e das concepções de sociedade difundidas pelos discursos políticos partidários, sindicais, religiosos e outros. A difícil articulação entre processos de consciência e as práticas dos movimentos sociais merece ser aprofundada.

De qualquer forma, ao trazer aqui memórias sobre um momento da história feminista, podemos pensar que as mudanças culturais podem ocorrer simultaneamente a outras lutas sociais de classe, porque presente e projeto de futuro se entrecruzam na riqueza das experiências humanas. Como afirmava Marx, mais rico será o indivíduo quanto mais possibilidades ele tiver de exercer a sua subjetividade. A história continua. 


\section{Referências}

ALVAREZ, S. Politizando as relações de gênero, engendrando a democracia. In: BASTOS, M. B. Outras palavras, outras imagens: movimentos feministas na cidade de São Paulo nos anos 70/80. São Paulo: PUC/SP, 1992.

ANDRADE, M. de P. Conflitos agrários e memória de mulheres camponesas. Estudos Feministas, Florianópolis, v. 15, n. 2, p. 445-451, maio/ago. 2007.

BAKHTIN, M. A cultura popular na idade média e no renascimento: o contexto de François Rabelais. São Paulo: Hucitec, 1987.

BOSI, E. Entre a opinião e o estereótipo. Novos Estudos, n. 32, mar. 1992.

CHAUÍ, M. Em torno da política do corpo. Mulherio, São Paulo, ano 2, n. 6, mar./abr. 1982.

DELPHY, C. Feminismo e recomposição da esquerda. Estudos Feministas, Rio de Janeiro: CIEC/UFRJ, v. 2, n. 3, 1994.

IASI, M. L. O dilema de Hamlet: o ser e o não ser da consciência. São Paulo: Viramundo, 2002.

MARTINS, M. Marxismo e subjetividade: uma leitura dos Manuscritos de 44. In: SILVEIRA, P.; DORAY, B. (Org.). Elementos para uma teoria marxista da subjetividade. São Paulo: Vértice, Revista dos Tribunais, 1989.

SMITH, R. C. História oral na historiografia: autoria na história. História Oral, v. 13, n. 1, p. 23-32, jan./jun. 2010. Disponível em: <http://revista.historiaoral.org.br/index.php? journal $=$ rho\&page $=$ article $\&$ op $=$ viewFile $\&$ path $\% 5 B \% 5 \mathrm{D}=128 \&$ path $\% 5 B \% 5 \mathrm{D}=124>$. Acesso em: 20 maio 2011.

PAOLI, M. C. As ciências sociais, os movimentos sociais e a questão de gênero. Novos Estudos, São Paulo, n. 31, p. 107-120, 1991.

PINTO, C. R. J. Feminismo, história e poder. Revista Sociologia e Politica, Curitiba, v. 18, n. 36, p. 15-23, jun. 2010.

POLLAK, M. Memória e identidade social. Estudos Históricos, Rio de Janeiro, v. 5, n. 10, p. 200-212, 1992.

SCOTT, J. Gênero: uma categoria útil para análise histórica. Revista Educação e Realidade, Porto Alegre, jul./dez. 1990. 
SCOTT, J. História das mulheres. In: BURKE, P. (Org.). A escrita da história. São Paulo: Novas Perspectivas; Unesp, 1992.

SINGER, P. O feminino e o feminismo. In: SINGER, P.; BRANT, V. Säo Paulo, o povo em movimento. 2. ed. Petrópolis: Vozes; Cebrap, 1981.

SOUZA-LOBO, E. A classe operária tem dois sexos. São Paulo: Brasiliense, 1991.

THOMPSON, E. P. A formação da classe operária inglesa. Rio de Janeiro: Paz e Terra, 1987.

Resumo: $\mathrm{O}$ artigo relaciona movimentos sociais de mulheres e feministas com narrativas de 12 ativistas do Comitê de Mulheres de São Bernardo do Campo (Brasil). A partir das narrativas, verifica se a participação nos movimentos sociais na década de 1980 permitiu a apropriação de concepções feministas e transformações de si. Por meio de análise de entrevistas e material documental da entidade, conclui-se que mudanças culturais e econômicas acontecem de modo dialético e que mulheres trabalhadoras questionam e redefinem elementos de seu cotidiano a partir de experiências sociais feministas. Em muitos sentidos, conseguem vivenciar o que alguns estudos afirmam existir apenas para mulheres de setores médios, devido à alta escolaridade e à equiparação econômica com seus parceiros que as levariam a novas concepções de gênero e poder.

Palavras-chave: feminismo, movimento social, mulheres, gênero.

\section{Feminist experiences and self-transformation of working women in the 80's}

Abstract: This article addresses women's social movements and feminist activists with life-long narratives of 12 activists from the Women's Committee of São Bernardo do Campo, Brazil. It verifies if the participation in social movements in the 1980s allowed self-transformation and appropriation of feminist ideas. Analysis of interviews and documentary materials of the entity allowed us to conclude that economic and cultural changes happen in a dialectic way and that working women question and redefine elements of their everyday life based on feminist social experiences. In many ways, they can experience what some studies claim there is only for women of middle sectors, due to the high educational level and economic comparison with their partners that lead them to new conceptions of gender and power.

Keywords: feminism, social movements, women, gender.

Recebido em 05/06/2011

Aprovado em 10/08/2011 